\title{
Mercury in archaeological human bone: biogenic or diagenetic?
}

\author{
Steven D. Emslie ${ }^{\mathrm{a}, *}$, Audrey Alderman ${ }^{\mathrm{a}}$, Ashley McKenzie ${ }^{\mathrm{a}}$, Rebecka Brasso ${ }^{\mathrm{b}}$, Alison R. Taylor ${ }^{\mathrm{a}}$, \\ María Molina Moreno ${ }^{c}$, Oscar Cambra-Moo ${ }^{c}$, Armando González Martín ${ }^{c}$, Ana Maria Silva ${ }^{\text {d,e,f }}$, \\ António Valera ${ }^{g}$, Leonardo García Sanjuán ${ }^{\mathrm{h}}$, Eduardo Vijande Vila ${ }^{\mathrm{i}}$ \\ ${ }^{\text {a }}$ Department of Biology and Marine Biology, University of North Carolina Wilmington, Wilmington, NC, USA \\ ${ }^{\mathrm{b}}$ Department of Zoology, Weber State University, Ogden, UT, USA \\ ${ }^{\mathrm{c}}$ Laboratorio de Poblaciones del Pasado (LAPP), Departamento de Biología, Facultad de Ciencias, Universidad Autónoma de Madrid, Campus de Cantoblanco, 28049, \\ Madrid, Spain \\ ${ }^{\mathrm{d}}$ Laboratory of Prehistory, Research Centre for Anthropology and Health, Department of Life Sciences, University of Coimbra, Coimbra, Portugal \\ ${ }^{\mathrm{e}}$ UNIARQ, University of Lisbon, Portugal \\ ${ }^{\mathrm{f}}$ Centre for Functional Ecology (CEF), Department of Life Sciences, University of Coimbra, Coimbra, Portugal \\ ${ }^{\mathrm{g}}$ Era Arqueologia / ICArEHB - Universidade do Algarve, Portugal

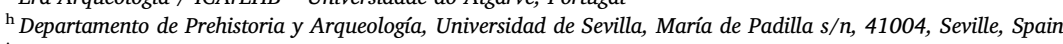 \\ ${ }^{i}$ Departamento de Historia, Geografía y Filosofía, Facultad de Filosofía y Letras, Universidad de Cádiz, 11003, Cádiz, Spain
}

\section{A R T I C L E I N F O}

\section{Keywords:}

Iberia

Neolithic

Chalcolithic

Bronze age

Cinnabar

Pigments

Toxicity

Bone remodeling

SEM EDS

\begin{abstract}
A B S T R A C T
We investigated mercury $(\mathrm{Hg})$ in human bone from archaeological sites in the Iberian Peninsula where the cultural use of cinnabar (HgS) as a pigment, offering or preservative in burial practices has been documented from the 4th to 2nd millennia cal B.C. (Late Neolithic, Copper Age and Bronze Age). Previous analyses have shown high levels of total mercury ( $\mathrm{THg}$ ) in human bone at numerous Neolithic and Chalcolithic sites in this region, but the question remains if this mercury entered the bones via diagenetic processes in the soil, especially where cinnabar powder and paint was found associated with the burials, or if it entered the bone via biogenic pathways from exposure to mercury from using cinnabar in life. We analyzed the humerus, femur, and tibia from a total of 30 individual burials from four Neolithic to Bronze Age sites in Iberia and found low to high values of $\mathrm{THg}$ in these bones, with the humerus showing significantly more THg concentrations than other skeletal elements when the THg was greater than $1 \mathrm{ppm}$. This pattern of $\mathrm{Hg}$ deposition in skeletal material from different sites and ages strongly suggests a biogenic origin for the mercury. In addition, absence of detectable $\mathrm{Hg}$ in bones with high to low values of THg using SEM EDS analysis further discounts diagenetic intrusion of $\mathrm{Hg}$ or cinnabar particles into the bone from the soil. It is likely that greater stress and bone remodeling rates from use of heavy tools and other activities in life are responsible for higher THg in the humerus than other skeletal elements, but additional research is needed to verify this.
\end{abstract}

\section{Introduction}

A new direction in bioarchaeology in recent years has been the analysis of mercury $(\mathrm{Hg})$ in human bone, especially in prehistoric cultures that used cinnabar ( $\mathrm{HgS})$ as a mineral pigment, preservative, medicinal or other use (Emslie et al., 2015; Ochoa-Lugo et al., 2017; Cervini-Silva et al., 2018). Cinnabar forms as a precipitate in volcanic and thermal regions with deposits known worldwide, including Europe, Asia, and the Americas. Prehistoric use of this mineral in the form of red pigment has been documented in most places worldwide where it occurs naturally, though mining and continuous use of this mineral can result in toxic exposure to inorganic mercury. Mercury exposure in humans also can occur via methylmercury ( $\mathrm{MeHg}$ ), which bioaccumulates and biomagnifies in food webs and can lead to acute or chronic mercury poisoning (Driscoll et al., 2013). This dietary pathway of exposure, since it is related to increasing mercury concentrations in species higher up the food chain, is typically correlated with higher concentrations of the heavier nitrogen isotope, $\delta^{15} \mathrm{~N} \%$, which also increases with trophic level of diet (Jardine et al., 2006; Blévin et al., 2013).

Mineral pigments, especially red from ochres (iron oxides), have a long archaeological record dating as far back as 200,000 to 300,000 years ago in Africa (Siddall, 2018). These pigments have been used as paint for rock art, body decoration, or in ceramics and as such need to

\footnotetext{
${ }^{*}$ Corresponding author. Tel.: +01910 9623357.

E-mail address: emslies@uncw.edu (S.D. Emslie).
} 
be mixed with a binder or medium such as plant oils or egg yolk. Bright red colors also were symbolic of blood, life, and vitality as has been documented in modern hunter-gatherer societies around the world (Siddall, 2018). Cinnabar has been mined and traded along the silk road in China for at least 2000 years (Sevillano-López and González, 2011) and since the Late Middle Neolithic in Portugal (Valera et al., 2017) and the Late Neolithic in Spain (Hunt-Ortiz et al., 2011; Bueno-Ramírez et al., 2019). Powdered cinnabar not only provided a bright red pigment (brighter than ochre) when mixed with a medium, but as mercury sulfide also has a long history of medicinal uses in China and India (Liu et al., 2008) as well as serving as a preservative in human burials. Medicinal uses include oral doses of mercurial salts as a sedative and to treat fever, insomnia, stroke, trauma to the brain, mouth and tongue ulcers, and other ailments (Liu et al., 2018). When mixed into an ointment, cinnabar has been used to treat syphilis and as an antipediculosis for head lice (Rasmussen et al., 2008; Fornaciari et al., 2011).

Powdered cinnabar pigment has been found associated with prehistoric human burials in Japan, Chile, Peru, Mexico, and Iberia (Yamada et al., 1995; Martín Gil et al., 1995; Cooke et al., 2009, 2013; Hunt-Ortiz et al., 2011; Domingo et al., 2012; Rogerio-Candelera et al., 2013; Ávila et al., 2014; García Sanjuán et al., 2016; Ochoa-Lugo et al., 2017; Arriaza et al., 2018; Cervini-Silva et al., 2013, 2018; BuenoRamírez et al., 2019), though whether the pigment was applied to these burials as a preservative or for a ceremonial function (the bright red color signifying blood and life) is not readily apparent in most of these situations. Powdered cinnabar also was found associated with burials at the Neolithic/Chalcolithic site of Perdigões, Portugal, where analyses first revealed high levels of total mercury ( $\mathrm{THg}$ ) in human bone that was attributed to the cultural use of cinnabar in life (Emslie et al., 2015). At the Chalcolithic tholos of Montelirio, cinnabar paint was used to coat the large slate slabs that formed the walls of the mortuary chambers implying a symbolic and ceremonial function (García Sanjuán et al., 2016). Seven individuals buried within this tholos also had moderate to high levels of THg in their bones (Emslie et al., 2016).

While high levels of $\mathrm{THg}$ have been detected in human bone in burials associated with cinnabar, the question remains whether this mercury intruded into the bone via diagenetic processes or if it was deposited during bone growth and remodeling via a biogenic pathway from $\mathrm{Hg}$ exposure from mining, processing and/or using cinnabar in life. Here, we examine this question in detail with analyses of archaeological human bone from four sites dating to the Late Neolithic, Copper Age and Early Bronze Age in Iberia. We also completed scanning electron microscope (SEM) analysis of two bones with high and low mercury concentrations, respectively, to assess diagenetic penetration of the bone. These data are presented with a review of the literature on the toxicity of cinnabar and how $\mathrm{Hg}$ can become deposited in bone via a biogenic pathway.

\section{Materials and methods}

We analyzed associated skeletal material from four sites in Iberia: the Middle Neolithic necropolis of Campo de Hockey, Cadiz, Spain ( $\mathrm{N}=18$ burials; Vijande Vila, 2009; Vijande Vila et al., 2015), the Late Neolithic site of Monte da Comenda, Portugal $(\mathrm{N}=3)$, the Late Neolithic/Chalcolithic site of Monte Canelas I, Portugal $(\mathrm{N}=3$; Silva, 1996), and the Early Bronze Age site of La Encantada, Granátula de Calatrava, Ciudad Real, Spain ( $=7$; Galán Saulnier and Sánchez Meseguer, 2014, Fig. 1 and Table 1). These sites were chosen not only because they contained individual burials so that different skeletal elements from the same individual could be sampled, but also because they span a period of time that extends from before the first known use of cinnabar in Iberian prehistory (Middle Neolithic) to the end of its use in burials by the Bronze Age. These analyses supplement an earlier analysis of associated skeletal elements of 12 individuals from the Chalcolithic Montelirio tholos (Emslie et al., 2016).
Bone was sampled by taking a section of cortical bone from the shaft of the humerus, femur, and/or tibia, when present in individual burials. The samples were then washed and scrubbed in running distilled water and air dried. A NSK Ultimate XL micromotor drill with a coarse bur was used to remove the outer cortex of the bone and expose clean inner compact bone. The drill and work area were wiped clean with ethanol, then a $2 / 32$ carbide bur was used to remove a sample of inner compact bone onto a clean sheet of aluminum foil. This powdered bone was stored in a clean plastic vial until analysis in a Tri-cell Direct Mercury Analyzer (DMA-80, Milestone, Inc.). Each sample run in the DMA-80 was based on $0.01-0.02 \mathrm{~g}$ of bone powder. Up to 20 samples were analyzed per run and preceded and followed by two method blanks, a sample blank, and two samples each of standard reference material (DORM-4 and DOLT-5 from fish protein and dogfish liver, respectively, and certified by the National Research Council, Canada). Two to three replicate runs of each sample were completed when THg concentrations were greater than $2 \mathrm{ppm}$ to obtain a mean \pm s.d. Mean percent recoveries for standard reference materials were $100.3 \% \pm 2.8 \%$ (DORM4) and $92.2 \% \pm 1.8 \%$ (DOLT-5). The relative significant difference for replicates for both standard reference materials was $<7.0 \%$ throughout duration of the present study.

In some cases, duplicate samples also were analyzed in a separate laboratory using a thermal decomposition Nippon MA-3000 mercury analyzer (Nippon Instruments Corp., Japan). Each sample run was completed with $0.01-0.05 \mathrm{~g}$ of bone powder with two samples each of TORT3 standard reference material before and after the run. Mean percent recovery for TORT3 was $98.5 \% \pm 1.1 \%$ and the relative significant difference was $3.9 \%$.

Scanning electron microscopy and Energy-dispersive X-ray Spectroscopy (EDS) were completed on selected bone samples at the University of North Carolina Greensboro. Samples were mounted onto aluminum stubs (Electron Microscopy Sciences, Hatfield, PA, USA) using carbon sticky tape and coated with $10 \mathrm{~nm}$ of PtPd using a Cressington sputter coater (208HR, Cressington, Watford, UK). Two samples of human bone were analyzed (UE-112 and UE-113) together with a pig bone fragment included as a negative control known to have low THg exposure. UE 112 and 113 are humeri from the Montelirio tholos, Spain (Chalcolithic; Emslie et al., 2016). Analysis of THg from these bones using the DMA-80 indicated high THg content in UE 112 (273.5 ppm) and low content in UE 113 (10.7 ppm). Here, each of these bones was analyzed twice at two magnifications $(28 \times$ and $100 x)$ with spectra acquired from several separate regions of interest (ROI). Samples were imaged using a Zeiss Auriga scanning electron microscope (Carl Zeiss Microscopy, NY, USA) equipped with x-ray dispersive spectroscopy (X-Flash 5030, Bruker, PA, USA). The incident electron beam acceleration was set to $15 \mathrm{KeV}$ with 500,000 events collected for each spectrum. Spectrum acquisition ranged from 2000 to 4000 counts $\mathrm{s}^{-1}$ with a dead time of $<3 \%$ and total live-time of $100-150 \mathrm{~s}$ per spectrum. Bruker Quantax Espirit software was used for both acquisition and analysis. Manual-interactive background subtraction of bremsstrahlung was performed before standardless quantification of relevant peaks using the $\mathrm{P} / \mathrm{B}-\mathrm{ZAF}$ method.

We used chi-square tests $(2 \times 2$ table $)$ with $\mathrm{df}=1$ to test for significance in THg distribution among skeletal elements with alphas set at $\mathrm{P}<0.05$.

\section{Results}

Middle Neolithic: Campo de Hockey is located in the Bay of Cádiz, the southernmost region of the Iberian Peninsula in Spain. Geo-archaeological studies have confirmed that, during the Neolithic, this marshy area was mostly under the sea, the most elevated areas in both the city and its immediate hinterland forming small islets (Arteaga et al., 2008). In 2007, the construction of a hockey stadium exposed the remains of this Late Neolithic settlement, dated at the end of the 5th millennium and the beginning of the 4 th millennium (4221 - 3708 B.C.; 


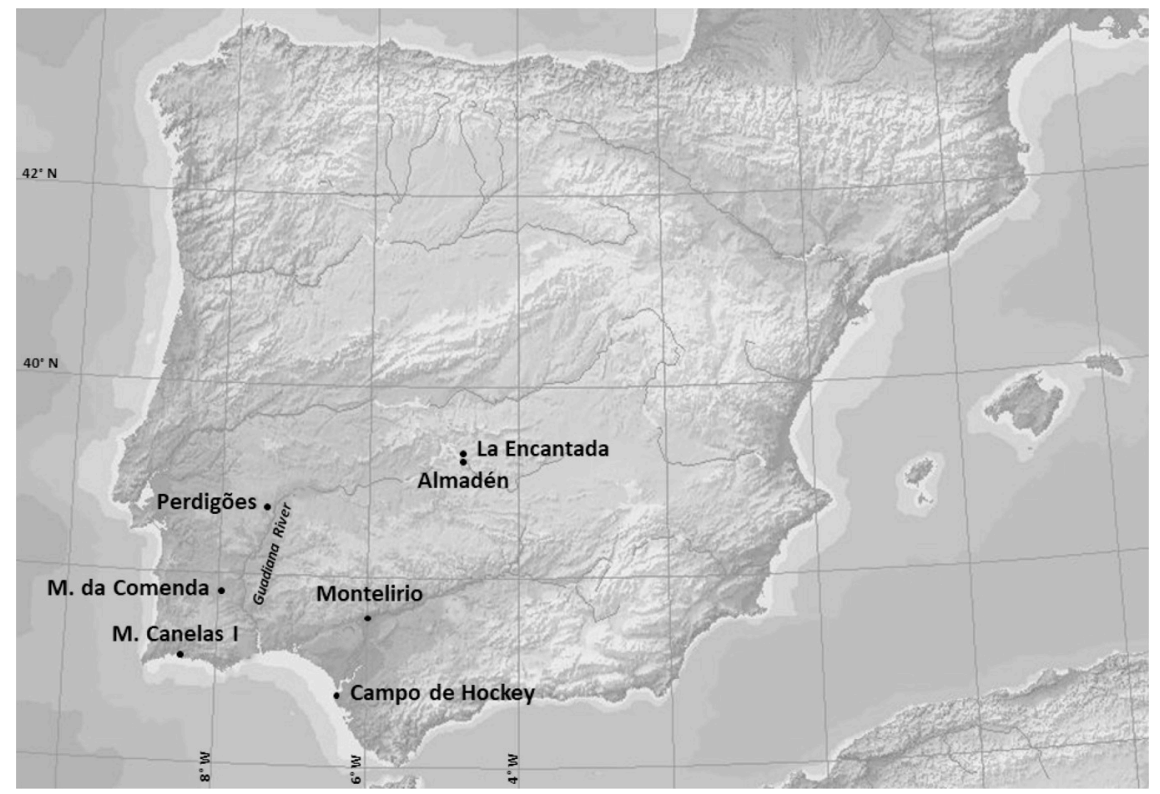

Fig. 1. Map of Iberia showing the locations of archaeological sites where human bones have been analyzed for THg (four reported here for the first time), and the location of the Almadén cinnabar mine, Spain.

Vijande Vila, 2009). Different types of graves exist, from simple burial pits to burial mounds or more elaborate graves (Vijande Vila, 2009; Vijande Vila et al., 2015). A total of 60 graves have been excavated to date, including 49 (82\%) individual graves, eight double graves and two quadruple graves, amounting to a total of 73 individuals. The presence of rich grave offerings (beads made of amber, variscite and turquoise, and imported polished axes) in the most elaborate graves is a clear indication of social differentiation. No cinnabar has been identified at this site or found associated with any of these burials.

Of the 18 burials studied here, all had low THg concentrations in all three skeletal elements analyzed (THg $<2-3 \mathrm{ppm}$; Supplementary data). Because the concentrations were all $<2 \mathrm{ppm}$, additional duplicate analyses were not considered necessary. Seven individuals had higher THg concentrations in the humerus compared to the femur and tibia (Fig. 2A); an eighth individual (UE 1213) also had slightly higher THg in the humerus but the values were so low in each bone $(<0.071 \mathrm{ppm})$ that the results are not considered meaningful. The seven individuals with highest concentrations in the humerus (range $0.52-2.45 \mathrm{ppm}$ ) overall also had higher THg measurements in all three bones compared to the other eleven burials. In these eleven burials, no pattern in skeletal element concentrations emerges and neither the femur $(N=5)$ or the tibia $(N=6)$ had higher concentrations than the other elements.

Late Neolithic: Monte da Comenda is a hypogeum in the Beja district of southern Portugal that has been radiocarbon dated at 4405 - 4361 B.P (Valera, 2018), or 2455 - 2411 B.C. A minimum number of 12 individuals were buried here. Two of three burials (UE 431 and 442) were analyzed for $\mathrm{THg}$ in the humerus and tibia (no femora present), while the humerus and femur were analyzed in the third (UE 448; no tibia present; Fig. 2B). All three burials had low to high levels in one or more elements. In UE 431, the humerus and tibia had high levels ( $>58 \mathrm{ppm}$ ) with the former element slightly higher than the latter. In UE 448, low levels of THg were highest in the humerus. UE 442 had moderate levels of $\mathrm{THg}$ in both elements, but the tibia had on average over twice as high a concentration as the humerus (Supplementary data).

Late Neolithic/Chalcolithic: The Monte Canelas I hypogeum was excavated in the early 1990s and consists of a small corridor leading to two underground burial chambers (Silva, 1996). Thousands of human bone fragments were recovered and two burial layers were separated by limestone rock. Five primary inhumations were found placed in fetal positions in the lower level, dated at 3200 B.C. (Silva, 1996), but only three were recovered in situ and were analyzed here. While only the humerus and tibia was present from one of these burials, all three individuals had moderate levels of mercury in their bones (range 2.2-7.5 ppm) and higher THg concentrations in the humerus compared to other elements (Fig. 2C), similar to findings at La Encantada described below.

Early Bronze Age: La Encantada is a necropolis, defensive structure and temple site located on top of an $800 \mathrm{~m}$ high hill above the Jabalón River valley, Spain. Excavations began there in 1977 and uncovered 82 burials dating from 1850 to 1450 B.C. (Sánchez Meseguer and Galán

Table 1

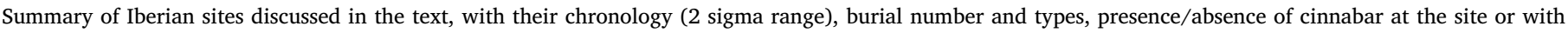

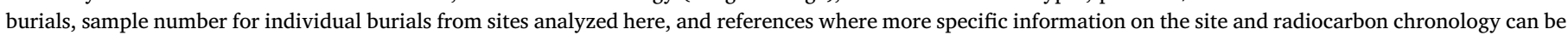
found. Note that Perdigões has produced hundreds of individuals from collective funerary burial and cremation pits.

\begin{tabular}{|c|c|c|c|c|c|c|}
\hline Site & $\begin{array}{l}\text { Radiocarbon chronology } \\
\text { (B.C.) }\end{array}$ & Burial Type & MNI & Cinnabar & Sampled individuals No. & References \\
\hline Campo de Hockey, Spain & $4221-3708$ & Individual and multiple & 73 & no & 18 & Vijande (2009); Vijande Vila et al. (2015) \\
\hline Perdigões, Portugal & $3400-2100$ & Collective (pits, tholoi) & & yes & - & Valera et al. (2014) \\
\hline Monte Canelas I, Portugal & $3020-2420$ & Collective (hypogeum) & 5 & no & 3 & Silva (1996) \\
\hline Montelirio, Spain & $2875-2635$ & Collective (tholos) & 26 & yes & 11 & Fernández Flores et al. (2016) \\
\hline Monte da Comenda, Portugal & $2455-2411$ & Collective (hypogeum) & 12 & no & 3 & Valera (2018) \\
\hline La Encantada, Spain & $1850-1450$ & Individual & 82 & no & 7 & $\begin{array}{l}\text { Sánchez Meseguer and Galán Saulnier (in } \\
\text { press) }\end{array}$ \\
\hline
\end{tabular}



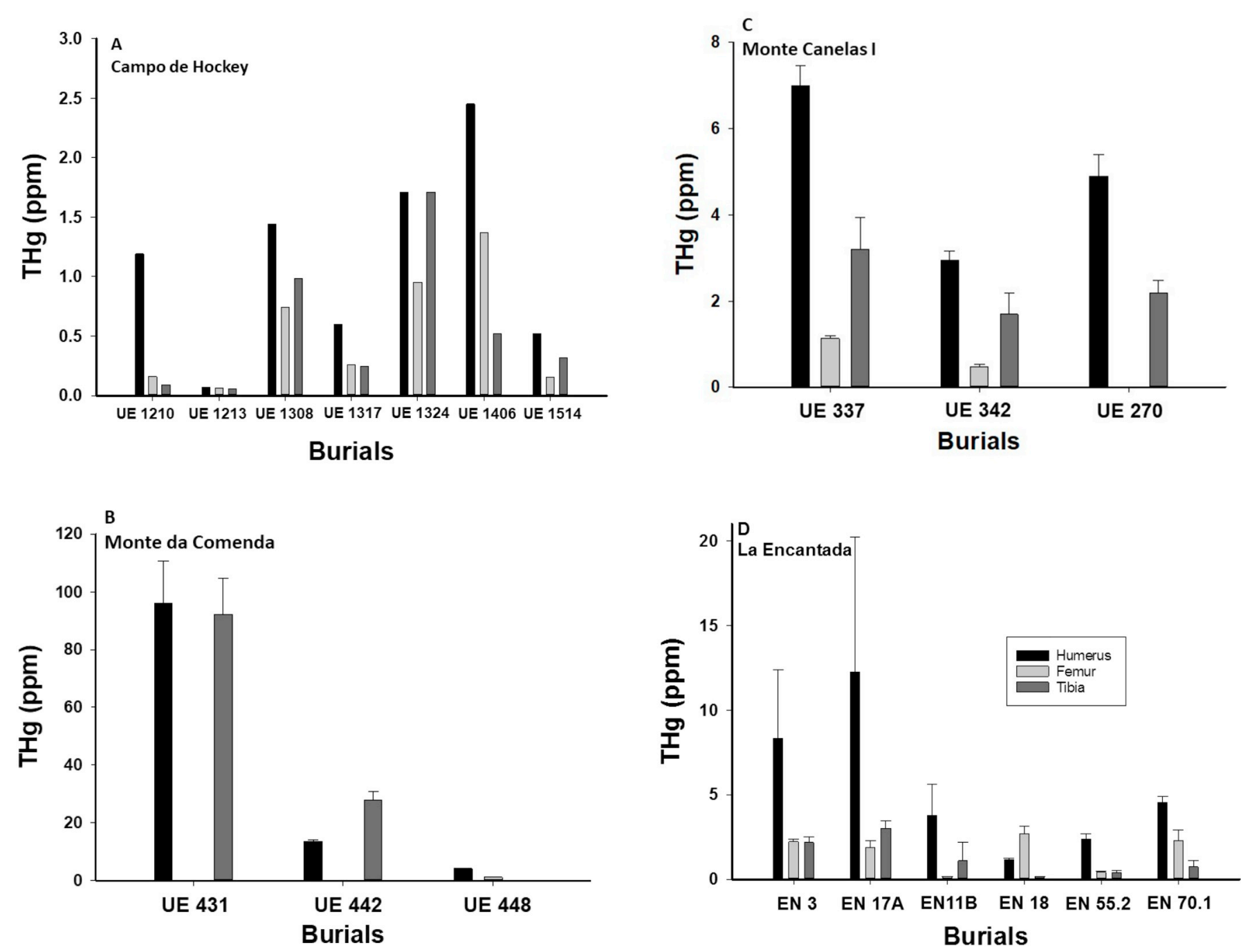

Fig. 2. Relative concentrations of THg (in ppm) in associated burials from (A) Campo de Hockey, Spain, (B) Monte da Comenda, Portugal, (C) Monte Canelas I, Portugal, and (D) La Encantada, Spain, that consistently indicate the humerus receives more Hg deposition than the femur and/or tibia. Shading of bars in all graphs is given in legend in D, with humerus, femur, and tibia illustrated for each burial (labelled with UE or EN numbers) from left to right, respectively. Note that samples from Campo de Hockey were only analyzed once, due to very low THg values, so the graph does not have error bars.

Saulnier, in press). No cinnabar was found associated with any of these burials. Seven individuals were analyzed here for THg of the humerus, femur and tibia. All individuals had low to moderate mercury concentrations in all skeletal elements; five of the seven individuals had higher THg values in the humerus (Fig. 2D). One individual (EN 58.1) had low THg values $(<0.35 \mathrm{ppm})$ in all three skeletal elements (see Supplemental data) and was not included in Fig. 2D.

Of all burials analyzed here $(\mathrm{N}=32), 17(53.1 \%)$ had higher $\mathrm{THg}$ in the humerus compared to the femur and/or tibia indicating no significant pattern in $\mathrm{Hg}$ distribution $\left(X^{2}=0.0322, \mathrm{df}=1, \mathrm{P}=0.86\right)$. When comparing only burials with $>1 \mathrm{ppm}$ THg in at least one of the bones $(\mathrm{N}=17)$, the percentage of individuals with a greater $\mathrm{THg}$ concentration in the humerus increases to $88.2 \%$ (15 of 17) and is significant $\left(X^{2}=4.023, \mathrm{df}=1, \mathrm{P}=0.045\right)$. The two exceptions to this pattern of compartmentalization of $\mathrm{Hg}$ among skeletal elements include UE 442 (Monte da Comenda, discussed above) and EN 18 (La Encantada).

SEM analysis: X-ray dispersive spectroscopy analysis of the two human bone samples (UE 112 and 113 described above) confirmed $\mathrm{Ca}_{5}\left(\mathrm{PO}_{4}\right)_{3}(\mathrm{OH})$ (hydroxyapatite) as the primary mineral, as evidenced by dominant peaks for $\mathrm{Ca}, \mathrm{O}$ and $\mathrm{P}$ (Figs. 3 and 4, Table 2). No significant $\mathrm{Hg}$ emission peaks were detected in the negative control pig bone ( $\mathrm{n}=1$ sample, 2 locations, 8 separate spectra, data not shown).
No significant $\mathrm{Hg}$ or $\mathrm{S}$ peaks were detected in either UE 112 ( $\mathrm{n}=3$ ROIs and spectra, Fig. 3 and Table 2) or UE $113(n=3$ ROIs and spectra, Fig. 4 and Table 2) from the Montelirio tholos, suggesting $\mathrm{Hg}$ and $\mathrm{S}$, if present, are well below the limit of detection for EDS. We also included larger areas of ROIs at 100x in UE 112 and UE 113 with similar results (Supplementary Figs. 1-2).

\section{Discussion}

Given that most mercury exposure in the Late Neolithic to Bronze Age of Iberia is likely due to cultural use of cinnabar (Emslie et al., 2015), it is important to review the toxicity of this mineral and potential biogenic and diagenetic pathways in which $\mathrm{Hg}$ from cinnabar may become deposited in human bone. This is particularly important as cinnabar is often spread over burials and has potential to penetrate bone via diagenetic processes. Biogenic exposure to $\mathrm{Hg}$, though, can occur from mining and processing cinnabar, or in using it as a body paint, medicinal, or other cultural use.

\subsection{Is cinnabar toxic?}

Cinnabar ore, by itself, is harmless and essentially insoluble in water (King, 2002). The mercury within it is bound to sulfur and thus in an 

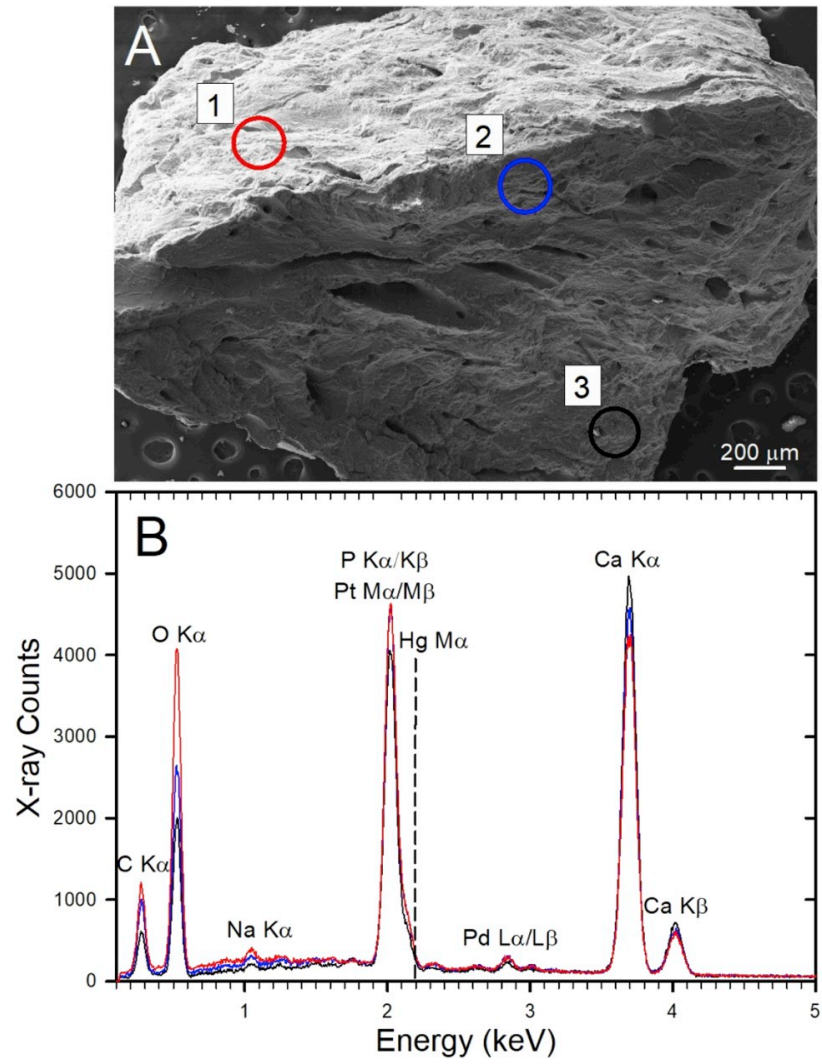

Fig. 3. EDS spectroscopy of human bone sample UE-112 from Montelirio tholos known to have high $\mathrm{THg}$ concentrations ( $>273 \mathrm{ppm}$ ). (A) Human bone sample UE-112 with three regions of interest (ROIs; black, blue and red) from which corresponding X-ray spectra were collected. (B) Three spectra from (A) ROIs are overlaid and major element X-ray emission peaks labelled. The primary $\mathrm{Hg} \mathrm{M} \alpha$ emission energy is indicated with a dotted black line. No significant $\mathrm{Hg}$ was detected in any of the bone samples examined. Magnification $28 \times$; scale bar on photo. (For interpretation of the references to color in this figure legend, the reader is referred to the Web version of this article.)

inert state. However, if subsequent chemical reactions release the inorganic mercury from this bond, it can enter the environment and methylate into the highly toxic methylmercury that can biomagnify up the food chain (Díez et al., 2011). In addition, numerous studies have now shown that mercury in cinnabar specifically can break down or metabolize via various organic pathways in animals including humans, ultimately causing harmful effects. Moreover, burning cinnabar will release the mercury into highly toxic $\mathrm{Hg}^{\mathrm{O}}$ vapor which also can result in chronic or lethal exposure if inhaled in sufficient quantities. So, while cinnabar itself is not toxic, processing and using cinnabar can be harmful or even lethal. For example, according to the World Health Organization (WHO; http://www.who.int/mediacentre/factsheets/ fs361/en), inhalation, ingestion or dermic exposure to mercury can cause neurological and behavioural disorders, including tremors, insomnia, memory loss, neuro-muscular effects, migraines and cognitive as well as motor dysfunctions.

Cases of mercury poisoning are well documented from the Almadén cinnabar mines of central Spain since the 16th century AD, including description of the symptoms suffered by the 'azogados', as the ill ones were referred to (from the Old Spanish word 'azogue', for mercury) (López Antón and Martínez Tarazona, 2018). Liu et al. (2008, 2018) provide reviews of cinnabar use and mercury exposure in Chinese medicinal practices. They describe applications of this mineral as a sedative and to treat various ailments including insomnia, inflammations, strokes, and epilepsy, all with limited impact from $\mathrm{Hg}$ exposure. Fornaciari et al. (2011) also report the likely use of ointments
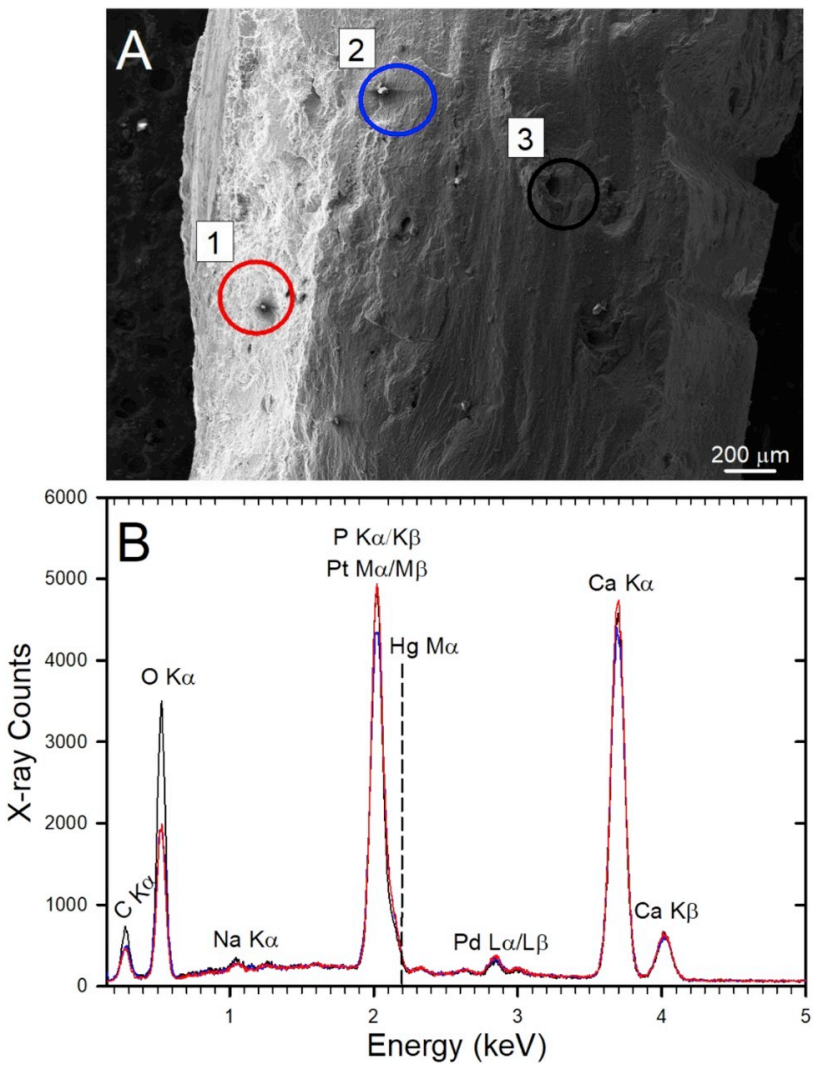

Fig. 4. EDS spectroscopy of human bone sample UE-113 Montelirio tholos known to have low $\mathrm{THg}$ concentrations ( $<11 \mathrm{ppm} \mathrm{ppm})$. (A) Human bone sample UE-113 with three regions of interest (ROIs; black, blue and red) from which corresponding X-ray spectra were collected. (B) Three spectra from (A) ROIs are overlaid and major element X-ray emission peaks labelled. The primary $\mathrm{Hg} \mathrm{M} \alpha$ emission energy is indicated with a dotted black line. No significant $\mathrm{Hg}$ was detected in any of the bone samples examined. Magnification $28 \times$; scale bar on photo. (For interpretation of the references to color in this figure legend, the reader is referred to the Web version of this article.)

containing mercury as an antipediculosis in mummified hair of Ferdinand II or Aragon, King of Naples, in 15th century Italy. Burning cinnabar and releasing mercury vapor, $\mathrm{Hg}^{\circ}$, can result in the highest levels of exposure with $80 \% \mathrm{Hg}$ absorption through the lungs (Clarkson et al., 2007; Park and Zheng, 2012). Absorption through the skin and gut are much lower at $0.2-1.0 \%$. Ointments and creams containing $\mathrm{Hg}$ can absorb through the epidermis and sweat glands, causing a lightning of the skin, but long-term use can result in rashes, nephritic syndromes, tremors, weakness, and insomnia (Park and Zheng, 2012). Although inorganic $\mathrm{Hg}$ absorption levels are much lower than exposure to the bioavailable and highly toxic methylmercury, continuous exposure to inorganic mercury and mercury salts will result in increased $\mathrm{Hg}$ concentrations in the kidney that can lead to renal failure (Wang et al., 2015). In children, the effects may be more permanent impacting brain and motor function when the $\mathrm{Hg}$ binds to enzymes that relate to neuron activities as shown in controlled experiments with mice dosed with cinnabar (Huang et al., 2012).

\subsection{Biogenic pathways of $\mathrm{Hg}$ in bone}

Numerous studies on mercury and other trace metal deposition in modern human and animal bone have been conducted that provide insight on how this might have occurred in archaeological bone. Whether exposed to either inorganic or methylmercury, $\mathrm{Hg}$ deposition in bone will follow the same chemical pathways during bone growth and remodeling. Blood carrying $\mathrm{Hg}, \mathrm{Pb}, \mathrm{Zn}, \mathrm{Sr}$ and other heavy and 
Table 2

Summary of quantification of weight percent (top) and atomic percent for human bone samples UE-112 and UE-113 at ROIs 1-3 given in Figs. 3 and 4, respectively.

UE-112 wt $\%$ Calculations

\begin{tabular}{llllllll}
\hline Spectrum & $\mathrm{C}$ & $\mathrm{O}$ & $\mathrm{Na}$ & $\mathrm{Mg}$ & $\mathrm{P}$ & $\mathrm{Ca}$ & $\mathrm{Pt}$ \\
\hline ROI-1 (UE-112 4.spx) & 7.27 & 35.30 & 0.29 & 0.02 & 10.54 & 34.79 & 10.14 \\
ROI-2 (UE-112 3.spx) & 7.57 & 28.56 & 0.35 & & 11.87 & 40.35 & 11.19 \\
ROI-3 (UE-112 1.spx) & 4.87 & 25.03 & 0.37 & 0.14 & 14.51 & 43.45 & 11.62 \\
Mean & $\mathbf{6 . 5 7}$ & $\mathbf{2 9 . 6 3}$ & $\mathbf{0 . 3 4}$ & $\mathbf{0 . 0 8}$ & $\mathbf{1 2 . 3 1}$ & $\mathbf{3 9 . 5 3}$ & $\mathbf{1 0 . 9 8}$ \\
StDev & 1.48 & 5.22 & 0.04 & 0.08 & 2.02 & 4.39 & 0.76 \\
\hline
\end{tabular}

UE-112 At\% Calculations

\begin{tabular}{|c|c|c|c|c|c|c|c|}
\hline Spectrum & $\mathrm{C}$ & $\mathrm{O}$ & $\mathrm{Na}$ & $\mathrm{Mg}$ & $\mathrm{P}$ & $\mathrm{Ca}$ & Pt \\
\hline ROI-1 (UE-112 4.spx) & 14.75 & 53.77 & 0.31 & 0.02 & 8.29 & 21.16 & 1.27 \\
\hline ROI-2 (UE-112 3.spx) & 16.22 & 45.97 & 0.39 & & 9.87 & 25.92 & 1.48 \\
\hline ROI-3 (UE-112 1.spx) & 11.25 & 43.40 & 0.45 & 0.16 & 13.00 & 30.08 & 1.65 \\
\hline Mean & 14.08 & 47.71 & 0.38 & 0.09 & 10.39 & 25.72 & 1.47 \\
\hline StDev & 2.55 & 5.40 & 0.07 & 0.10 & 2.40 & 4.46 & 0.19 \\
\hline
\end{tabular}

UE-113 wt $\%$ Calculations

\begin{tabular}{llllllll}
\hline Spectrum & $\mathrm{C}$ & $\mathrm{O}$ & $\mathrm{Na}$ & $\mathrm{Mg}$ & $\mathrm{P}$ & $\mathrm{Ca}$ & $\mathrm{Pt}$ \\
\hline ROI-1 (UE-113 1.spx) & 6.38 & 33.47 & 0.52 & 0.15 & 11.13 & 34.84 & 10.96 \\
ROI-2 (UE-113 2.spx) & 5.60 & 31.91 & 0.52 & 0.15 & 11.66 & 36.42 & 11.28 \\
ROI-3 (UE-113 3.spx) & 5.12 & 29.83 & 0.25 & & 11.60 & 39.45 & 11.32 \\
Mean & $\mathbf{5 . 7 0}$ & $\mathbf{3 1 . 7 3}$ & $\mathbf{0 . 4 3}$ & $\mathbf{0 . 1 5}$ & $\mathbf{1 1 . 4 6}$ & $\mathbf{3 6 . 9 0}$ & $\mathbf{1 1 . 1 9}$ \\
StDev & 0.64 & 1.82 & 0.15 & 0.00 & 0.29 & 2.34 & 0.19 \\
\hline
\end{tabular}

UE-113 At $\%$ Calculations

\begin{tabular}{llllllll}
\hline Spectrum & $\mathrm{C}$ & $\mathrm{O}$ & $\mathrm{Na}$ & $\mathrm{Mg}$ & $\mathrm{P}$ & $\mathrm{Ca}$ & $\mathrm{Pt}$ \\
\hline ROI-1 (UE-113 1.spx) & 13.40 & 52.79 & 0.57 & 0.15 & 9.07 & 21.94 & 1.42 \\
ROI-2 (UE-113 2.spx) & 12.09 & 51.71 & 0.58 & 0.16 & 9.76 & 23.56 & 1.50 \\
ROI-3 (UE-113 3.spx) & 11.38 & 49.82 & 0.29 & & 10.01 & 26.30 & 1.55 \\
Mean & $\mathbf{1 2 . 2 9}$ & $\mathbf{5 1 . 4 4}$ & $\mathbf{0 . 4 8}$ & $\mathbf{0 . 1 6}$ & $\mathbf{9 . 6 1}$ & $\mathbf{2 3 . 9 3}$ & $\mathbf{1 . 4 9}$ \\
StDev & 1.02 & 1.50 & 0.16 & 0.00 & 0.49 & 2.21 & 0.07 \\
\hline
\end{tabular}

trace elements will deposit these into cortical bone as it develops in newly forming bone in the young, or in cement lines or with microfractures from excess loading and strain during bone remodeling in fully grown adults (Miculescu et al., 2011; Pemmer et al., 2013). Thus, $\mathrm{Hg}$ concentrations are expected to vary between cortical and trabecular or cancellous bone, as well as among different skeletal elements. Research on cortical bone of the femoral neck in humans is most common as these bones are more available following hip surgeries and can be compared to the diet, age, sex and other criteria of the donor. These studies are in accordance with greater $\mathrm{Hg}$ and other metal deposition occurring in cortical bone of the femoral neck compared to cancellous bone of the femoral head (Lanocha et al., 2012, 2013; Pemmer et al., 2013; Ziola-Frankowska et al., 2017). The reasons for this difference include cortical bone remodeling more slowly and metal concentrations dependent on degree of mineralization (Ziola-Frankowska et al., 2017).

Analysis of $\mathrm{Hg}$ and other metals in animal bone also have shown higher concentrations in areas with greater $\mathrm{Hg}$ pollution, including both inorganic and methylmercury. Sanchez-Chardi et al. (2007) analyzed long bones of shrews in two regions of Spain, one (Ebro Delta) with heavy pollution and the other area, Medras Islands with no human habitation or pollution, as a control. They found significantly higher levels of $\mathrm{Hg}$ and $\mathrm{Pb}$ in bone from the polluted area.

In regard to soft tissues as well as bone, Brookens et al. (2008) examined $\mathrm{Hg}$ concentrations in Harbor Seal (Phoca vitulina) pups in California and found that relative concentrations were highest in hair, liver and kidney tissues, but lowest in bone. While the $\mathrm{Hg}$ exposure was likely from methylmercury in fish prey, these results suggest that bone is slow to absorb $\mathrm{Hg}$ compared to other tissues. Similar results were found in two groups of rats dosed with low and high levels of methylmercury over a 3-month period (Halffman, 2009). Only the kidney was examined in this study compared to several bones (cranium, cortical shaft of humerus and femur) with highest levels in both groups occurring in the kidney and lowest in all of three of the bones. Among the bones, the cranium had the highest concentrations of Hg followed by the cortical shafts of the humerus and femur.

Only two studies of $\mathrm{Hg}$ and other metal and trace element concentrations in bone of workers exposed to industrial pollutants have been conducted. Lindh et al. (1980) completed autopsies on workers exposed to mercury and other metals from chimney emissions at a smeltery and refinery in Sweden for over ten years. Their sample included seven individuals ranging from 45 to 75 years in age and five individuals from an unpolluted area as controls. Analysis of $\mathrm{Hg}$ and $\mathrm{Pb}$ in compact bone from the femoral shaft was compared to numerous other soft tissues. As with the Harbor Seal pups and rats, Hg concentrations were consistently lower in bone than in soft tissues. Garcia et al. (2001) completed a similar study with autopsies of 78 individuals who lived in a highly industrialized area of Spain for at least ten years before death. They found levels of $\mathrm{Hg}$ in the kidney averaging $0.25 \mathrm{ppm}$, and $0.14 \mathrm{ppm}$ in the liver, but bone had $<0.05 \mathrm{ppm}$. Finally, a study of autopsy tissues from 30 random individuals to examine trace element and heavy metal concentrations among various tissues, including brain, kidney, muscle, heart, and bone, again indicated $\mathrm{Hg}$ deposition was highest in the kidney and lowest in bone (Bush et al., 1995).

All of the above studies document clear biogenic patterns in $\mathrm{Hg}$ and other metal accumulation in bone. Cortical bone appears to be the largest sink for $\mathrm{Hg}$ deposition, but bone itself accumulates this metal at a much slower rate and lower concentration than soft tissues, especially hair, kidney, and liver. High concentrations of $\mathrm{Hg}$ in bone, then, must result from long-term repeated exposure to $\mathrm{Hg}$, whether in the inorganic elemental form or as the bioavailable methylmercury.

\subsection{Can mercury in cinnabar enter bone via diagenetic pathways?}

Although cinnabar is largely insoluble in water, it can break down and undergo dissolution by microorganisms or chemical reactions under certain environmental conditions, or by artificial means from retorting the mercury during mining operations which can result in $\mathrm{Hg}$ release into the environment. The natural conditions for dissolution of $\mathrm{HgS}$ include soils high in organic matter (e.g., tropical soils; BallandBolou-Bi et al., 2017) or mine waste waters high in Fe. Paquette and Helz (1995) reported that mercuric sulfide will dissolve in natural sulfidic, anoxic conditions at a $\mathrm{pH}$ range of 4-10, while Ravichandran et al. (1998) found that HgS will dissolve in humic soils at $\mathrm{pH}>6.0$ with high sulfide concentrations and hydrophobic acids. However, the presence of $\mathrm{Ca}$ will inhibit $\mathrm{HgS}$ dissolution. Because of these processes, as well as retorting activities, soils and plants around areas where cinnabar is mined have increased $\mathrm{Hg}$ concentrations compared to nonmined sites that may impact human populations living nearby (Williams et al., 1999; Qiu et al., 2006; Díez et al., 2011; JiménezMoreno et al., 2016).

Trace and heavy elements, including metals, can enter bone from the soil and penetration increases with decay as bone porosity increases over time (Hedges and Millard, 1995). Contamination can occur by the soil directly entering bone spaces and pores, or dissolved elements could replace $\mathrm{Ca}$ in the bone structure as mineralization proceeds. Concentrations of $\mathrm{Al}, \mathrm{Fe}$, and $\mathrm{Mn}$ can increase in bone from the soil by these pathways (Rasmussen et al., 2013a). However, for Hg specific environmental conditions are required for this to occur. García-Alix 
et al. (2012) attribute the red color of Miocene fossil mammals from the Granada Basin, southern Spain, to cinnabar penetration during diagenesis in a lacustrine, high organic environment. Cinnabar dissolved and then precipitated out in pores of the bones and teeth early in diagenesis, but did not become part of the bone or tooth structure. $\mathrm{Hg}$ concentrations ranged from 4513 to $19,332 \mathrm{ppm}$ and were highest in bone compared to dentine because of additional pore space in the former tissue.

In regard to archaeological bone, Yamada et al. (1995) reported mercury levels in bones from 6th-12th century burials in Japan. They found very high levels $(\sim 500->1500 \mathrm{ppm})$ in burials from different tombs, but soil analysis revealed little or no mercury. The authors speculated that the high levels in the bone were due to paint placed on the body after death, but no additional study was conducted. Rasmussen et al. (2008) examined mercury in the femur of 110 medieval burials of Danish friars and monks at several cemeteries. Most had $\mathrm{Hg}$ levels at $<1.0 \mathrm{ppm}$, but soil next to and up to $20 \mathrm{~cm}$ away (vertically and horizontally) from three burials indicated decreasing concentrations with greater distances from the bone. The high $\mathrm{Hg}$ levels near bones was attributed to $\mathrm{Hg}$ released from the soft tissues of the bodies through decay and they concluded that no transport of $\mathrm{Hg}$ took place from soil to bone, but rather the reverse. The $\mathrm{Hg}$ was biogenic in origin from using inks and medicines containing mercury to treat diseases (syphilis, leprosy). Similar results were found in a later study at another cemetery (Rasmussen et al., 2013b).

Cervini-Silva et al. (2013, 2018) and Ochoa-Lugo et al. (2017) analyzed two vertebrae from a temple at Palenque, Mexico, using Scanning Electron Microscope imagery and Energy-dispersive X-ray Spectroscopy (SEM-EDS) for mercury content. One bone was from inside a sarcophagus where thick layers of cinnabar covered a female burial (the 'Red Queen'), while the bone from outside the tomb had more exposure to diagenetic processes. The authors found that $\mathrm{Hg}$ from cinnabar had only penetrated a small layer of the outer cortex of bone in the sarcophagus, which had high levels of detectable $\mathrm{Hg}$ and nanotubular structures rich with $\mathrm{HgS}$, while inner cortical bone below this layer had undetectable levels of Hg. Nanotubular structures similar to collagen fibrils and evidence of fungal activity in particular were wellpreserved and were attributed to the antibacterial activity of $\mathrm{HgS}$ (Cervini-Silva et al., 2013). For bone samples from outside the sarcophagus, the $\mathrm{Hg}$ was distributed more homogeneously throughout the bone and the authors concluded that this bone had been exposed to $\mathrm{Hg}$ via biogenic pathways. Ochoa-Lugo et al. (2017) expanded on these studies with an analysis of mercury-enriched teeth from a female skeleton also found outside of the sarcophagus where the Red Queen was located. EDS was applied to determine the chemical composition of the enamel, dentin, and pulp on $1 \mathrm{M}$ and $\mathrm{Hg}$ was detected at $24.1-37.4 \%$ concentrations among all three compartments, and as high as $66 \%$ on the outside of the tooth. The authors attributed these results to oxidation of sulfur and release of $\mathrm{Hg}$ that penetrated the teeth via tubules and ion exchange with $\mathrm{Ca}$.

Emslie et al. (2015) reported moderate to high levels of Hg in Late Neolithic/Chalcolithic human bone from Perdigões, Portugal, that they attributed to the cultural use of cinnabar and exposure to $\mathrm{Hg}$ in life. This conclusion was based on the lack of any correlation in $\mathrm{Hg}$ and $\delta^{15} \mathrm{~N}$ concentrations in the bone that would indicate methylmercury exposure via diet, or between bone and associated soil found still attached on the outside or inside the shaft of the bone. Moreover, five animal bones from the site had very low concentrations of $\mathrm{Hg}(<0.02 \mathrm{ppm})$. SEM EDS analysis also failed to register any detectable levels of $\mathrm{Hg}$ in selected bone samples, nor were intrusive particles of soil or cinnabar evident in the bone pores or inner structure. The authors also applied $\mathrm{Hg}$ isotope analysis to identify the source of the $\mathrm{Hg}$ in two human bone samples from Perdigões that traced the mercury to cinnabar from mines at Almadén, Spain, the largest source of $\mathrm{Hg}$ in the world today. This study documented the earliest evidence of chronic mercury exposure in humans, and was the first use of $\mathrm{Hg}$ isotope tracking in an archaeological context.

Last, Emslie et al. (2016) studied mercury concentrations in six associated skeletons recovered from the Chalcolithic Montelirio tholos, Spain (Fernández Flores et al., 2016). These burials, mostly adult women, were found in association with cinnabar powder spread over and around some of the burials, and cinnabar paint coating the surface of many of the slate slabs used to line the sides of the tholos chambers and passage leading to them (Hunt Ortiz and Hurtado Pérez, 2010). Analysis of the humerus, femur, and tibia, when present in these burials revealed $\mathrm{Hg}$ concentrations varied from low to high, but that in five of the burials the humerus had higher $\mathrm{Hg}$ concentrations than the other two skeletal elements. This pattern suggests a biogenic origin for the $\mathrm{Hg}$ in the bone, but why the humerus would accumulate higher concentrations of $\mathrm{Hg}$ than other long bones remains unknown. Another tomb located near Montelirio and built at a slightly earlier period, Structure 10.042-10.049, also presented significant evidence of cinnabar use (Rogerio-Candelera et al., 2013). It is worth noting that tomb 10.042-10.049 and the Montelirio tholos, both of which yielded sumptuous grave goods made from various types of exotica (amber, ivory, rock crystal, flint), remain to this date the only contexts in which cinnabar has been found within the Valencina de la Concepción-Castilleja de Guzmán Copper Age mega-site of which they are part. It has been suggested that these two tombs belong to a connected lineage of high-ranking, elite individuals from the early 3rd millennium cal B.C. (García Sanjuán et al., 2018).

\subsection{Diagenetic or biogenic?}

Our SEM EDS analysis here supports the biogenic hypothesis for $\mathrm{Hg}$ deposition in bone. This analysis revealed no detectable levels of mercury in the bone matrix or pore spaces in two bones with high and low THg measured using the DMA-80. This result also demonstrates that the $\mathrm{Hg}$ levels at any one ROI, a point $<200 \mu \mathrm{m}$ in diameter, the $\mathrm{Hg}$ is low or undetectable. However, when bone is sampled with a micromotor drill so that a relatively large area of cortical bone is included in the powdered sample for analysis (0.01-0.02 g), the mercury levels are measureable. These results indicate that the $\mathrm{Hg}$ is unevenly distributed within the bone matrix where it was deposited via blood flow during bone growth and remodeling. This uneven distribution is in accordance with studies of metal deposition in bone with higher concentrations along cement lines and where microfractures have occurred (Pemmer et al., 2013), or with distal versus proximal shafts as remodeling rates vary with loading and strain with age (Lieberman et al., 2003).

Our results also indicate that when overall THg concentrations in long bones are higher than $\sim 1 \mathrm{ppm}$, the humerus is significantly more likely to contain greater concentrations of $\mathrm{THg}$ than the femur or tibia. This pattern was first noted in five of six burials that included $\mathrm{THg}$ analysis of the humerus, femur and/or tibia at the Chalcolithic Montelirio tholos, Spain (Emslie et al., 2016). To find a similar pattern from four other archaeological sites that differ in age by thousands of years and occur in different depositional environments is striking.

These results suggest that relatively high or constant exposure to $\mathrm{Hg}$, whether from methylmercury in diet or inorganic mercury from using or processing cinnabar, the human humerus is subject to higher depositional rates than the femur or tibia. This pattern likely results from higher bone remodeling rates via biomechanical regulation in the humerus (Robling and Turner, 2009), perhaps from use of heavy tools and other activities in life. Under stress, bone remodeling may change the thickness and shape of the bone, or act to repair microcracks at the Haversian level (Lieberman et al., 2003). Neolithic to Bronze Age peoples undoubtedly experienced heavy labor in farming, animal husbandry, construction, and other strenuous activities. In this respect, at least three of the 11 individuals sampled from the Montelirio tholos (large burial chamber) seem to present a correlation between high $\mathrm{THg}$ levels and musculo-skeletal markers commonly associated with intense physical activity (García Sanjuán et al., 2016). Individual UE 346 
(probably female) who yielded a result of $255.88 \mathrm{ppm}$ of THg showed marked development of the linea aspera in her femur; individual UE 109 (adult female) with $84.14 \mathrm{ppm}$ of $\mathrm{THg}$ in her humerus showed musculo-skeletal stress markers in both her legs and hands. Finally, individual UE 113 (adult female) with $132.21 \mathrm{ppm}$ THg recorded in her femur, showed evidence of dorso-lumbar spondilo-arthrosis as well as arthrosis in her right knee and her hip. Potentially, therefore, it is possible to establish correlations between concentrations of $\mathrm{THg}$ in long bones and the individual's personal history of physical activity, provided the necessary musculo-skeletal stress-marker data are available.

It is possible that the increased loading and strain on some bones, particularly the humerus, would result in more remodeling and thus, more $\mathrm{Hg}$ deposition in this element compared to others analyzed here. The two exceptions to this pattern, burials UE 442 and EN 18, cannot be explained except that the high levels of THg in the tibia of the former perhaps resulted from greater use and stress in the legs than the arms in life. EN 18 from La Encantada had very low levels of THg in all three skeletal elements analyzed $(<2.15 \mathrm{ppm})$ and only in higher concentrations does the pattern with the humerus emerge completely. La Encantada also dates to the Early Bronze Age, when cinnabar use in Iberia was waning and it no longer appears with burials. The highest concentration of THg measured from this site was in the humerus of burial EN 3 at 12.86 ppm (Supplemental data). Biogenic $\mathrm{Hg}$ exposure at La Encantada likely occurred from environmental pollution from living near the Almadén mine, where impacts of this mining are still measurable today (Diez et al., 2011). Ultimately, these results provide strong evidence that the $\mathrm{Hg}$ in bone is biogenic as it is unlikely that this pattern could occur via diagenetic processes at now five sites of different ages and locations. This hypothesis can be tested with additional analyses, including other skeletal and cranial elements not sampled here. Investigation of other metals (e.g., Pb) or minerals (e.g., Sr) that deposit in bone via similar pathways from blood with bone growth and remodeling (Rasmussen et al., 2015) also may reveal similar patterns among the skeletal elements that would support this hypothesis.

\section{Conclusions}

Although more $\mathrm{Hg}$ isotope tracking would be beneficial to determine if cinnabar from Almadén or other mines is the source of the $\mathrm{Hg}$ in archaeological human bone in Late Prehistoric Iberia, whether the $\mathrm{Hg}$ is from cinnabar or methylmercury from dietary exposure, our data here provide strong support for a biogenic pathway into cortical bone. We report for the first time a pattern in $\mathrm{Hg}$ concentrations among skeletal elements, with the humerus usually having higher levels than the femur or tibia, at five sites (four reported here) across Iberia that range in age from Middle Neolithic to Bronze Age. These results warrant further investigation on the compartmentalization of $\mathrm{Hg}$ and other metals and minerals among human skeletal elements. We also found that the amounts of $\mathrm{Hg}$ in human bone are highest in high-ranking burials such as at Montelirio tholos and Structure 10.042-10.049 at the Copper Age mega-site of Valencina. In Montelirio not only did some of the deceased have remarkably high levels of mercury in their bones, cinnabar was also heavily used in various ways: as a thick coating covering the slate slabs lining the walls of the tomb, and sprayed over the bodies. The study of this tomb suggests that cinnabar-based pigments were very important socially (possibly as a means to distinguish a special group of people, in this case interpreted as priestesses, or the elite) and ideologically (because of its symbolic value, red color being a pervasive presence in the tomb; García Sanjuán et al., 2016). In Early Bronze Age cinnabar is also documented (López Padilla e al. 2012) although less frequently and in far smaller quantities, which is in accordance with the decline of the trading networks for exotic raw materials in this period.

The widespread, pervasive use of cinnabar as a socially and culturally important material further suggests that it is highly unlikely that the presence of mercury in human bone developed at so many sites of different chronologies, locations, and soil conditions by diagenetic means. Clearly the humerus receives greater concentrations from a biogenic pathway that may relate to greater blood flow and higher remodeling rates that result in more $\mathrm{Hg}$ deposition in this bone than in other skeletal elements. While additional diagenetic pathways need to be explored, especially in situations where $\mathrm{Hg}$ is mobilized from $\mathrm{HgS}$ in humic soils, this study provides baseline data for advancing this new area of bioarchaeology and mercury exposure from the cultural use of cinnabar that can be applied to other regions where this important and valuable mineral was available to prehistoric peoples.

\section{Declaration of interests}

- The authors declare that they have no known competing financial interests or personal relationships that could have appeared to influence the work reported in this paper.

- The authors declare the following financial interests/personal relationships which may be considered as potential competing interests:

\section{Acknowledgements}

The SEM EDS analyses were performed in part at the Joint School of Nanoscience and Nanoengineering, a member of the Southeastern Nanotechnology Infrastructure Corridor (SENIC) and National Nanotechnology Coordinated Infrastructure (NNCI), which is supported by the National Science Foundation (Grant ECCS-1542174). The Laboratorio de Poblaciones del Pasado (LAPP) was supported by Projects HAR2016-78036-P, HAR2016-74846-P, HAR2017-82755-P, HAR2017-83004-P (Spanish Government). Research at the University of Coimbra was supported by CIAS - (PEst-OE/SADG/UI0283/2019). Excavations at Campo de Hockey were supported by Project I + D HAR2017-87324-P (Spanish Government). Research conducted by ERA and Icarehb was funded by FCT in the project PTDC/EPH-ARQ/0798/ 2014.

\section{Appendix A. Supplementary data}

Supplementary data to this article can be found online at https:// doi.org/10.1016/j.jas.2019.05.005.

\section{References}

Arriaza, B., Ogalde, J.P., Campos, M., Paipa, C., Leyton, P., Lara, N., 2018. Toxic pigment in a Capacocha burial: instrumental identification of cinnabar in Inca human remains from Iquique, Chile. Archaemet. https://doi.org/10.1111/arcm.12392.

Arteaga, O., Schulz, H., Roos, A.M., 2008. Geoarqueología Dialéctica en la Bahía de Cádiz. In: Arteaga, O., Schulz, H. (Eds.), Geoarqueología y proceso histórico en la Bahía de Cádiz. Revista Atlántica-Mediterránea dePrehistoria y Arqueología Social 10, pp. 21-116.

Ávila, A., Mansilla, J., Bosch, P., Pijoan, C., 2014. Cinnabar in Mesoamerica: poisoning or mortuary ritual? J. Archaeol. Sci. 49, 48-56.

Balland-Bolou-Bi, C., Turc, B., Alphonse, V., Bousserrhine, N., 2017. Impact of microbial communities from tropical soils on the mobilization of trace metals during dissolution of cinnabar ore. J. Environ. Sci. 56, 122-130.

Blévin, P., Carravieri, A., Jaeger, A., Chastel, O., Bustamante, P., Cherel, Y., 2013. Wide range of mercury contamination in chicks of southern ocean seabirds. PLoS One 8 e54508. https://doi.org/10.1371/journal.pone.0054508.

Brookens, T.J., O'Hara, T.M., Taylor, R.J., Bratton, G.R., Harvey, J.T., 2008. Total mercury body burden in Pacific harbor seal, Phoca vitulina richardii, pups from central California. Mar. Pollut. Bull. 56, 27-41.

Bueno-Ramírez, P., Barroso-Bermejo, R., de Balbín-Behrmann, R., 2019. Funerary red (cinnabar versus ochre) and megalithic rituals in the central Iberian peninsula. Bull. Soc. Prehistor. Française 116, 73-93.

Bush, V.J., Moyer, T.P., Batts, K.P., Parisi, J.E., 1995. Essential and toxic element concentrations in fresh and formalin-fixed human autopsy tissues. Clin. Chem. 41/2, 284-294.

Cervini-Silva, J., de Lourdes Muñoz, M., Palacios, E., Jimenez-Lopex, J.C., RomanoPacheco, A., 2018. Ageing and preservation of HgS-enriched ancient human remains deposited in confinement. J. Archaeol. Sci.: For. Rep. 18, 562-567.

Cervini-Silva, J., Palacios, E., Muñóz, M.L., del Angel, P., Montoya, J.A., Ramos, E., Romano-Pacheco, A., 2013. Cinnabar-preserved primary osteogenesis and fungal- 
activity signatures in ancient human remains. Geomicrobiol. J. 30, 1-12.

Clarkson, T.W., Vyas, J.V., Ballatori, N., 2007. Mechanisms of mercury disposition in the body. Am. J. Ind. Med. 50, 757-764.

Cooke, C.A., Balcom, P.H., Biester, H., Wolfe, A.P., 2009. Over three millennia of mercury pollution in the Peruvian Andes. Proc. Natl. Acad. Sci. Unit. States Am. 106, 8830-8834.

Cooke, C.A., Hintelmann, H., Ague, J.J., Burger, R., Biester, H., Sachs, J.P., Engstrom, D.R., 2013. Use and legacy of mercury in the Andes. Environ. Sci. Technol. 47, 4181-4188.

Díez, S., Esbrí, J.M., Tobias, A., Higueras, P., Martínez-Coronado, A., 2011. Determinants of exposure to mercury in hair from inhabitants of the largest mercury mine in the world. Chemosphere 84, 571-577.

Driscoll, C.T., Mason, R.P., Chan, H.M., Jacob, D.J., Pirrone, N., 2013. Mercury as a global pollutant: sources, pathways, and effects. Environ. Sci. Technol. 47, 4967-4983.

Domingo, I., García-Borja, P., Roldán, C., 2012. Identification, processing and use of red pigments (hematite and cinnabar) in the Valencian Early Neolithic (Spain). Archaeometry 54, 868-892.

Emslie, S.D., Brasso, R., Patterson, W., Valera, A.C., McKenzie, A., Silva, A.M., Gleason, J.D., Blum, J.D., 2015. Chronic mercury exposure in Late Neolithic/Chalcolithic populations in Portugal from the cultural use of cinnabar. Sci. Rep. 5, 14679. https:// doi.org/10.1038/srep14679.

Emslie, S.D., McKenzie, A.C., Shaller, H.E., 2016. Análisis de mercurio de los restos hu manos del Tholos de Montelirio. In: Fernández Flores, A., García Sanjuán, L., DíazZorita Bonilla, M. (Eds.), Montelirio Un gran monumento megalítico de la Edad del Cobre, Arqueología Monografías. Junta de Andalucia, Spain, pp. 449-454.

Fernández Flores, A., García Sanjuán, L., Díaz-Zorita Bonilla, M. (Eds.), 2016. Montelirio Un gran monumento megalítico de la Edad del Cobre. Arqueología Monografías, Junta de Andalucia, Spain.

Fornaciari, G., Marinozzi, S., Gazzaniga, V., Giuffra, V., Picchi, M.S., Giusiani, M., Masetti, M., 2011. The use of mercury against pediculosis in the renaissance: the case of Ferdinand II of aragon, king of Naples, 1467-96. Med. Hist. 55, 109-115.

Galán Saulnier, C., Sánchez Meseguer, J.L., 2014. Problemas de la Edad del Bronce: los "curenos de la consagración" en la Península Ibérica. Arqueoy + Monografías 5.

Garcia, F., Ortega, A., Domingo, J.L., Corbella, J., 2001. Accumulation of metals in autopsy tissues of subjects living in Tarragona County, Spain. Environ. Sci. Health A36, 1767-1786.

García-Alix, A., Minwer-Barakat, R., Suárez, E.M., Freudenthal, M., Huertas, A.D., 2012. Cinnabar mineralization in fossil small mammal remains as a consequence of diagenetic processes. Lethaia 46, 1-6.

García Sanjuán, L., Fernández Flores, Á., Díaz-Zorita Bonilla, M., 2016. Montelirio. Valoración e Interpretación de una tumba excepcional. In: Fernández Flores, Á. García Sanjuán, L., Díaz-Zorita Bonilla, M. (Eds.), Montelirio: Un Gran Monumento Megalítico de la Edad del Cobre. Junta de Andalucía, Sevilla, pp. 503-553.

García Sanjuán, L., Luciañez Triviño, M., Cintas-Peña, M., 2018. Ivory, elites and lineages in Copper Age Iberia: exploring the wider significance of the Montelirio tomb. Madrider Mitteilungen 59, 23-65.

Halffman, C.M., 2009. Bone as a Biomarker of Mercury Exposure in Prehistoric Arctic Human Populations: Initial Method Validation Using Animal Models. PhD thesis. Univ. of Alaska, Fairbanks.

Hedges, R.E.M., Millard, A.R., 1995. Bones and groundwater: towards the modelling of diagenetic processes. J. Archaeol. Sci. 22, 155-164.

Huang, C.-F., Hsu, C.-J., Liu, S.-H., Lin-Shiau, S.-Y., 2012. Exposure to low dose cinnabar (a naturally occurring mercuric sulfide $(\mathrm{HgS})$ ) caused neurotoxicological effects in offspring mice. J. Biomed. Biotechnol. 254582. https://doi.org/10.1155/2012/ 254582.

Hunt-Ortiz, M., Hurtado Pérez, V., 2010. Pigmentos de sulfuro de mercurio (cinabrio) en contextos funerarios de época calcolítica en el Sur de la península Ibérica: investigaciones sobre el uso, depósitos minerales explotados y redes de distribución a través de la caracterización composicional composicional e isotópica. In: Sainz Carrasco, M.E., López Romero, E., Cano Díaz-Tendero, M.A., Calvo García, J.C. (Eds.), Actas del VIII Congreso Ibérico de Arqueometría (Teruel, 19-21 de Octubre de 2009). Teruel, University of Zaragoza, pp. 123-132.

Hunt-Ortiz, M.A., Consuegra-Rodríguez, S., Díaz del Río-Español, P., Hurtado-Pérez, V.M., Montero-Ruíz, I., 2011. Neolithic and Chalcolithic -VI to III Millennia BC- use of cinnabar ( $\mathrm{HgS})$ in the Iberian Peninsula: analytical identification and lead isotope data for an early mineral exploitation of the Almadén (Ciudad Real, Spain) mining district. In: In: Ortiz, J.E., Puche, O., Rábano, I., Mazadiego, L.F. (Eds.), History of Research in Mineral Resources, vol. 13. Cuadernos del Museo Geominero, Madrid, pp. 3-13.

Jardine, T.D., Kidd, K.A., Fisk, A.T., 2006. Applications, considerations, and sources of uncertainty when using stable isotope analysis in ecotoxicology. Environ. Sci. Technol. 40, 7501-7511.

Jiménez-Moreno, M., Barre, J.P.G., Perrot, V., Bérail, S., Martín-Doimeadios, R.C.R., Amouroux, D., 2016. Sources and fate of mercury pollution in Almadén mining district (Spain): evidences from mercury isotopic compositions in sediments and lichens. Chemosphere 147, 430-438.

King, R.J., 2002. Cinnabar. Geol. Today 18, 195-199.

Lanocha, N., Kalisinska, E., Kosik-Bogacka, D.I., Budis, H., Sokolowski, S., Bohatyrewicz, A., 2012. Concentrations of trace elements in bones of the hip joint from patients after hip replacement surgery. J. Trace Elem. Med. Biol. 26, 20-25.

Lanocha, N., Kalisinska, E., Kosik-Bogacka, D.I., Budis, H., Sokolowski, S., Bohatyrewicz Lanocha, A., 2013. The effect of environmental factors on concentration of trace elements in hip joint bones of patients after hip replacement surgery. Ann. Agric. Environ. Med. 20, 487-493.

Lieberman, D.E., Pearson, O.M., Polk, J.D., Demes, B., Crompton, A.W., 2003. Optimization of bone growth and remodeling in response to loading in tapered mammalian limbs. J. Exp. Biol. 206, 3125-3138.

Lindh, U., Brune, D., Nordberg, G., Wester, P.-O., 1980. Levels of antimony, arsenic cadmium, copper, lead, mercury, selenium, silver, tin and zinz in bone tissue of industrially exposed workers. Sci. Total Environ. 16, 109-116.

Liu, J., Shi, J.-Z., Yu, L.-M., Goyer, R.A., Waalkes, M.P., 2008. Mercury in traditional medicines: is cinnabar toxicologically similar to common mercurials? Exp. Biol. Med. 233, 810-817.

Liu, J., Wei, L.-X., Wang, Q., Lu, Y.-F., Zhang, F., Shi, J.-Z., Li, C., Cherian, M.G., 2018. A review of cinnabar (HgS) and/or realgar (As4S4)-containing traditional medicines. J. Ethnopharmacol. 210, 340-350.

López Antón, M.A., Martínez Tarazona, M.R. (Eds.), 2018. El Mercurio. Sus Fuentes de Emisión, Usos e Impactos. CSIC, Madrid.

López Padilla, J.A., De Miguel Ibáñez, M.P., Arnay De La Rosa, M., Galindo Martín, L., Roldán García, C., Murcia Mascarós, S., 2012. Ocre y cinabrio en el registro funerario de El Argar. Trab. Prehist. 69, 273-292.

Martín Gil, J., Martín Gil, F.J., Delibes De Castro, G., Zapatero Magdaleno, P., Sarabia Herrero, J., 1995. The first known use of vermillion. Cell. Mol. Life Sci. 51, 759-761.

Miculescu, F., Miculescu, M., Ciocan, L.,T., Ernuteanu, A., Antoniac, I., Pencea, I., Matei, E., 2011. Comparative studies regarding heavy elements concentration in human cortical bone. Digest J. Nanomat. Biostr. 6, 1117-1127.

Ochoa-Lugo, M., Cervini-Silva, J., de Lordes Muñoz, M., Palacios, E., Pérez-Ramirez, G., Ramos-Cruz, E., Montoya, A., Romano-Pacheco, A., 2017. The effect of depositional conditions on mineral transformation, chemical composition, and preservation of organic material in archaeological Hg-enriched bone remains. J. Archaeol. Sci.: For. Rep. 15, 213-218.

Paquette, K., Helz, G., 1995. Solubility of cinnabar (red HgS) and implications for mercury speciation in sulfidic waters. Water, Air, Soil Pollut. 80, 1053-1056.

Park, J.-D., Zheng, W., 2012. Human exposure and health effects of inorganic and elemental mercury. J. Prev. Med. Public Health 45, 344-352.

Pemmer, B., Roschger, A., Wastl, A., Hofstaetter, J.G., Wobrauschek, P., Simond, R. Thaler, H.W., Roschger, P., Klaushofer, K., Streli, C., 2013. Spatial distribution of the trace elements zinc, strontium and lead in human bone tissue. Bone 57, 184-193.

Qiu, G., Feng, X., Wang, S., Shang, L., 2006. Environmental contamination of mercury from Hg-mining areas in Wuchuan, northeastern Guizhou, China. Environ. Pollut. 142, 549e558. https://doi.org/10.1016/j.envpol.2005.10.015.

Rasmussen, K.L., Skytte, L., Pilekær, C., Lauritsen, A., Boldsen, J.L., Leth, P.M., Thomsen, P.O., 2013a. The distribution of mercury and other trace elements in the bones of two human individuals from medieval Denmark - the chemical life history hypothesis. Herit. Sci. 1, 10. https://doi.org/10.1186/2050-7445-1-10.

Rasmussen, K.L., Boldsen, J.L., Kristensen, H.K., Skytte, L., Hansen, K.L., Mølholm, L., Grootes, P.M., Nadeau, M.-J., Eriksen, K.M.F., 2008. Mercury levels in Danish Medieval human bones. J. Archaeol. Sci. 35, 2295-2306.

Rasmussen, K.L., Skytte, L., Ramseyer, N., Boldsen, J.L., 2013b. Mercury in soil surrounding medieval human skeletons. Heritage Sci 1, 16. http://www. heritagesciencejournal.com/content/1/1/16.

Rasmussen, K.L., Skytte, L., Jensen, A.J., Boldsen, J.L., 2015. Comparison of mercury and lead levels in the bones of rural and urban populations in Southern Denmark and Northern Germany during the Middle Ages. J. Archaeol. Sci. Rep. 3, 358-370.

Ravichandran, M., Aiken, G.R., Reddy, M.M., Ryan, J.N., 1998. Enhanced dissolution of cinnabar (mercuric sulfide) by dissolved organic matter isolated from the Florida Everglades. Environ. Sci. Technol. 32, 3305-3311.

Robling, A.G., Turner, C.H., 2009. Mechanical signaling for bone modeling and remodeling. Crit. Rev. Eukaryot. Gene Expr. 19, 319-338.

Rogerio-Candelera, M.A., Karen Herrera, L., Miller, A.Z., García Sanjuán, L., Mora Molina, C., Wheatley, D.W., Justo, A., Saiz-Jimenez, C., 2013. Red pigments used in burial practices at the Copper Age site of Valencina de la Concepción (Sevilla, Spain): characterisation and social dimension. J. Archaeol. Sci. 40, 279-290.

Sánchez Meseguer, J. L., Galán Saulnier, C., in press. La Cronología del Cerro de La Encantada: estratigrafía, dataciones radiocarbónicas y paleoclimatología. Calatrava Estudios 1.

Sanchez-Chardi, A., Lopez-Fuster, M.J., Nadal, J., 2007. Bioaccumulation of lead, mercury, and cadmium in the greatervwhite-toothed shrew, Crocidura russula, from the Ebro Deltav(NE Spain): sex- and age-dependent variation. Environ. Pollut. 145, 7-14.

Sevillano-López, D., González, F.J., 2011. Mining and minerals trade on the silk road to the ancient literary sources: $2 \mathrm{BC}$ to $10 \mathrm{AD}$ centuries. In: In: Ortiz, J.E., Puche, O., Rábano, I., Mazadiego, L.F. (Eds.), History of Research in Mineral Resources, vol. 13 Cuadernos del Museo Geominero, Madrid, pp. 43-60.

Siddall, R., 2018. Mineral pigments in archaeology: their analysis and the range of available materials. Minerals 8. https://doi.org/10.3390/min8050201.

Silva, A.M., 1996. Paleobiology of the population inumated in the Hipogeu of Monte Canelas I (Alcalar-Portugal). In: Actas Do XIII International Congress of Prehistoric and Protohistoric Sciences, Forlì, Itália, 8 - 14 September. vol. III. pp. 437-446.

Valera, A.C. (Ed.), 2018. Os Perdigões Neolíticos. Génese e desenvolvimento (de meados do $4^{\circ}$ aos inícios do $3^{\circ}$ milénio ac). NIA-ERA, Perdigões Monográfica, 1, Lisboa.

Valera, A.C., Fernandes, M., Simão, P., 2017. Os hipogeus da Pré-História Recente da Quinta da Abóbada. NIA-ERA Arqueologia, Apontamentos de Arqueologia e Património, 12, Lisboa, pp. 15-22.

Valera, A.C., Silva, A.M., Romero, J.E.M., 2014. The temporality of Perdigões enclosures: absolute chronology of the structures and social practices. SPAL 23, 11-26.

Vijande Vila, E., 2009. El poblado de Campo de Hockey (San Fernando, Cádiz): resultados preliminares y líneas de investigación futuras para elconocimiento de las formaciones sociales tribales en la Bahía de Cádiz(tránsito V-IV milenios a.n.e.). Rev. AtlánticaMediterránea de Prehist. Arqueol. Soc. 11, 265-284.

Vijande Vila, E., Domínguez-Bella, S., Cantillo Duarte, J.J., Martínez López, J., Barrena Tocino, A., 2015. Social inequalities in the neolithic of southern Europe: the grave goods of the Campo de Hockey necropolis (san Fernando, Cádiz, Spain). Comptes 
Rendus Palevol 14, 147-161.

Wang, Y., Wang, D., Wu, J., Wang, B., Gao, X., Wang, L., Ma, H., 2015. Cinnabar-induced subschronic renal injury is associated with increased apoptosis in rats. BioMed Res. Int. 278931. https://doi.org/10.1155/2015/278931.

Williams, T.M., Weeks, J.M., Apostol Jr., A.N., Miranda, C.R., 1999. Assessment of mercury contamination and human exposure associated with coastal disposal of waste from a cinnabar mining operation, Palawan, Philippines. Environ. Geol. 39,
51-60.

Yamada, M., Tohno, S., Tohno, Y., Minami, T., Ichii, M., Okazaki, Y., 1995. Accumulation of mercury in excavated bones of two natives in Japan. Sci. Total Environ. 162 253-256.

Ziola-Frankowska, A., Dąbrowski Kubaszewski, Ł., Rogala, P., Kowalski, A., Frankowski, M., 2017. An analysis of factors affecting the mercury content in the human femoral bone. Environ. Sci. Pollut. Res. 24, 547-557. 